\title{
Community structure and bioturbation potential of macrofauna at four North Sea stations with contrasting food supply
}

\author{
B. Dauwe*, P. M. J. Herman, C. H. R. Heip \\ Netherlands Institute of Ecology, Centre for Estuarine and Coastal Ecology (NIOO-CEMO), PO Box 140, 4400 AC Yerseke, \\ The Netherlands
}

\begin{abstract}
We investigated the macrobenthic faunal composition, vertical distribution, biomass, abundance and trophic structure in 4 North Sea sediments with contrasting quantity and quality of organic matter and with different hydrodynamic environments. The vertical distribution of macrofauna biomass generally followed the TOC (total organic carbon) profiles. The trophic structure reflected differences in relative quality of the organic matter. In the high amount-high quality TOC sediment at the German Bight station, most organisms were found at shallow sediment depths $\{2 \mathrm{~cm}\}$, mainly feeding on freshly deposited or (re-)suspended material as interface or suspension feeders. Skagerrak sediments, containing a large amount of refractory organic matter, supported a small-sized deeply penetrating fauna (up to $20 \mathrm{~cm}$ ) consisting mainly of deep-living deposit feeders and also endobenthic predators. Highest diversity of trophic groups, largest individual sizes and deepest distribution were found in sediment with organic matter of intermediate quantity and quality at the Frisian Front. The highly dynamic, coarse-grained Broad Fourteens sediments were very poorly inhabited, probably due to the extremely high hydrodynamic stress and low quantity of TOC. With the aid of a simple diagenetic model, we analysed the potential effect of bioturbation on the distribution of food in the investigated sediments. The model predicted for a given bioturbation coefficient that total mineralization rate at depth reaches an optimum when the arriving material is of intermediate quality, whereas it is not possible for macrofauna to redistribute the organic matter up to depth when the quality of the arriving material is high. The results of the diagenetic model agreed well with our characterization of the fauna community on the basis of principal bioturbation categories (species causing surface deposition, biodiffusion, conveyor belt transport). Strong mixing by biodiffusion was observed at the station which had organic matter of intermediate quality (Frisian Front) and minimal mixing at the German Bight station, which was characterized by the high quality of the arriving organic matter
\end{abstract}

KEY WORDS: North Sea Benthos - Trophic groups - Vertical distribution - Bioturbation - Organic matter

\section{INTRODUCTION}

Factors controlling benthic faunal abundance and biomass vary and often are site-specific. Changes in benthic community structure have been associated with biotic factors such as competition and predation (Rhoads \& Young 1970, Weinberg 1984) and abiotic factors such as water depth (Hyland et al. 1991), current velocity (Wildish \& Peer 1983), sediment stability (Probert 1984), sedimentation rate (Schaffner et al. 1987, Aller \& Stupakoff 1996), oxygen concentration

\footnotetext{
•E-mail: dauwe@cemo.nioo.knaw.nl
}

(Levin et al. 1991), silt content (Eleftheriou \& Basford 1989) and organic loading (Dauer \& Conner 1980). In particular, the amount and the nutritional quality of the organic material in the sediment is believed to play a key role influencing the biomass (Grebmeier et al. 1988), vertical distribution (Lin \& Hines 1994) and trophic structure of macrofaunal communities (Marsh \& Tenore 1990). On the other hand, macrofauna affects the distribution of organic matter in sediments by bioturbation (Wheatcroft 1990, Blair et al. 1996).

Pearson \& Rosenberg (1978) suggested that there are generalizable patterns of faunal community structure as a response to spatial or temporal changes in organic 
loading. As predicted by their succession model, increasing organic matter concentrations have indeed been found to lead to decreasing species diversity, increasing organism numbers and decreasing individual biomass per species (e.g. Valente et al. 1992). In addition, the succession model predicts a surficial depth distribution of the benthic community within the sediment and a shift towards deposit feeding as the organic enrichment increases (Pearson \& Rosenberg 1978, Rhoads \& Boyer 1982). Only recently have the vertical distribution (e.g. Weston 1990, Grehan et al. 1994, Flach \& Heip 1996) and the trophic structure (Gaston \& Nasci 1988, Gaston et al. 1988, Josefson 1986, Rosenberg 1995, Kube et al. 1996) of faunal communities been considered in the literature. The succession model and most studies relating macrofaunal community structure to organic matter do not explicitly take into account the nutritional quality of the organic matter available to the benthic community, despite the fact that systems with similar organic loading may contain organic matter with widely varying degradability and therefore different food value for benthic organisms (Dauwe \& Middelburg 1998).

Few attempts have been made to relate the bioturbation potential to organic matter profiles in marine sediments (Romero-Wetzel 1991). Structural (e.g. abundance, depth distribution) and behavioral (e.g. trophic guild) differences between macrofaunal communities are thought to influence bioturbation mechanisms and therefore the vertical distribution and availability of food within the sediment (Wheatcroft \& Martin 1996). Since most studies of sediment mixing do not include detailed faunal analysis, the influence of these aspects on sediment mixing is still poorly understood.

The objective of this paper is therefore 2-fold: Firstly, we relate the structural variations in North Sea macrofaunal communities to the quantity and quality of the sedimentary organic matter and point out drawbacks of the succession model when organic matter quality is also considered as a variable. Secondly, we investigate the possible effect of bioturbation on organic carbon mineralization deep in the sediment using a simple diagenetic model.

\section{MATERIAL AND METHODS}

Study area. The depth of the North Sea gradually increases from less than $30 \mathrm{~m}$ in the south to about $200 \mathrm{~m}$ in the northern part. To the northeast, in the Skagerrak region, the sea floor steeply slopes down to more than $700 \mathrm{~m}$. Most of the primary production occurs in the nutrient rich, well-mixed waters of the shallow Southern Bight and along the eastern boundary. The bulk of the organic material reaching the sediment in this area consists of labile material originating from direct deposition of phytoplankton blooms (North Sea Task Force 1993). Eisma \& Kalf (1987) showed that the counterclockwise residual currents transport fine-grained material in suspension from the Southern Bight along the eastern boundaries of the North Sea towards the Skagerrak (Fig. 1). The labile organic material becomes progressively more refractory due to aging and a series of sedimentationresuspension events during transport (Dauwe \& Middelburg 1998), and the deep depositional Skagerrak is assumed to be the ultimate sink for organic material originating from the southern North Sea (Eisma \& Kalf 1987, van Weering et al. 1993). The sample sites were chosen to reflect gradients along the general transport route of organic material in the North Sea and to show maximal differences in organic matter quantity and quality (Dauwe \& Middelburg 1998).

Characteristics of the sample stations. During a cruise with the RV 'Pelagia' in August 1994 sediment samples were collected at 4 stations in the North Sea (Fig. 1): Broad Fourteens (BF), Frisian Front (FF), Ger-

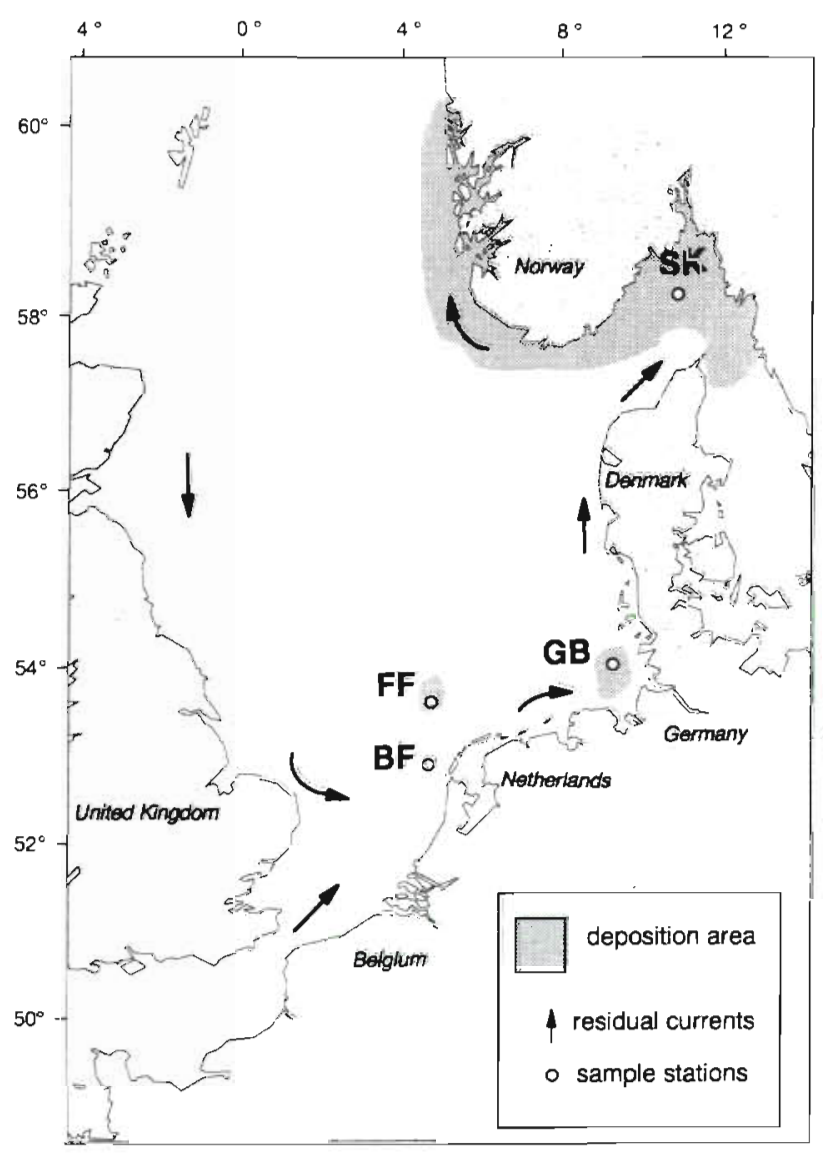

Fig. 1. Sample stations in the North Sea. BF: Broad Fourteens FF: Frisian Front; GB: German Bight; SK: Skagerrak. Arrows indicate the residual tidal currents 
man Bight (GB) and Skagerrak (SK). The water column at the shallow stations was completely mixed because of stormy weather; only the $280 \mathrm{~m}$ deep SK was stratified, with a minimum water temperature of $6^{\circ} \mathrm{C}$ at the bottom (Table 1).

Broad Fourteens: This is a coarse-grained erosional area. High current velocities of up to $40 \mathrm{~cm} \mathrm{~s}^{-1}$ at BF keep most of the organic matter in suspension. The extremely low organic carbon content and very low chlorophyll a content of the sediment indicate that no net deposition occurs at this site (Table 1), although during slack tide organic matter may temporarily reach the sediment surface (Jennes \& Duineveld 1996). Both the organic material supplied to the sediment and the organic matter preserved in the sediment are very labile as indicated by their high chlorophyll a/total organic carbon (TOC) ratio (Boon \& Duineveld 1996) and amino acid composition (Dauwe \& Middelburg 1998). Also, the high turnover rates and low biomass of sedimentary bacteria (van Duyl \& Kop 1994) show that the organic matter is highly degradable.
Frisian Front: At FF the tidal current velocity drops below a critical value, enabling fine-grained material to settle from the water column. The Frisian Front is a transition area between the permanently mixed southern North Sea and the deeper, temperature stratified central area (de Gee et al. 1991). During summer stratification, favorable conditions for localized high primary production are generated in this frontal area, leading to high sedimentation of organic matter (Creutzberg et al. 1984). The prolonged seasonal input of organic matter of intermediate quality (de Gee et al. 1991) leads to sediments with intermediate quality and organic loading. Compared to the adjacent Stn BF, $>10$ times more chlorophyll $a$ is incorporated in this sediment. All these characteristics indicate that fresh organic material reaching the sea floor is quickly incorporated and mineralized by benthic heterotophs.

German Bight: In the German Bight, residence times of the water are long due to a counterclockwise circulation pattern in the Bight. In addition, the level of inorganic nutrients is generally high due to strong river-

Table 1. General characteristics of the sample stations. Near surface flow velocity rates generally vary during tidal cycles and also vary seasonally. The given values are indications of the present flow regimes, indicating the maximum flow velocities reached during a tidal cycle (Boon \& Duineveld 1996). Total organic carbon (TOC), total nitrogen (TN), grain size and chlorophyll a measurements were determined following the methods described in Dauwe \& Middelburg (1998); enzymatically available amino acids (EHAA) and total hydrolyzable amino acids (THAA) were analyzed as described in Dauwe et al. (in press) following the method of Mayer et al. (1995). Values were integrated over the 0 to $20 \mathrm{~cm}$ depth stratum; S: 0-1 cm, D: 1-20 cm. Sources: (1) Dauwe \& Middelburg 1998; (2) de Haas \& van Weering (1997) and pers. comm.; (3) van Duyl \& Kop (1994), 0-6.2 cm sediment stratum $_{i}(4)$ Boon \& Duineveld (1996), sediment trap \pm 3 m above sediment surface; (5) Dauwe et al. (in press)

\begin{tabular}{|c|c|c|c|c|c|c|c|c|c|}
\hline & \multicolumn{2}{|c|}{$\begin{array}{c}\text { Broad Fourteens } \\
53^{\circ} 00^{\prime} \mathrm{N} \\
3^{\circ} 52^{\prime} \mathrm{E}\end{array}$} & \multicolumn{2}{|c|}{$\begin{array}{c}\text { Frisian Front } \\
53^{\circ} 42^{\prime} \mathrm{N} \\
4^{\circ} 30^{\prime} \mathrm{E}\end{array}$} & \multicolumn{2}{|c|}{$\begin{array}{l}\text { German Bight } \\
54^{\circ} 05^{\prime} \mathrm{N} \\
8^{\circ} 09^{\prime} \mathrm{E}\end{array}$} & \multicolumn{2}{|c|}{$\begin{array}{c}\text { Skagerrak } \\
58^{\circ} 12^{\prime} \mathrm{N} \\
10^{\circ} 15^{\prime} \mathrm{E}\end{array}$} & Source \\
\hline \multicolumn{10}{|l|}{ Water column } \\
\hline Temperature of bottom water $\left({ }^{\circ} \mathrm{C}\right)$ & \multicolumn{2}{|c|}{17.7} & \multicolumn{2}{|c|}{17} & \multicolumn{2}{|c|}{18.8} & \multicolumn{2}{|c|}{6.5} & (1) \\
\hline Salinity $(\%)$ & \multicolumn{2}{|c|}{34.6} & \multicolumn{2}{|c|}{34.3} & \multicolumn{2}{|c|}{31.2} & \multicolumn{2}{|c|}{35.1} & (1) \\
\hline Water depth $(\mathrm{m})$ & \multicolumn{2}{|c|}{28} & \multicolumn{2}{|c|}{39} & \multicolumn{2}{|c|}{20} & \multicolumn{2}{|c|}{270} & (1) \\
\hline Near surface flow velocity (max.) (cm s-1) & \multicolumn{2}{|c|}{$30-40$} & \multicolumn{2}{|c|}{$10-35$} & \multicolumn{2}{|c|}{$15-40$} & \multicolumn{2}{|c|}{$5-10$} & (4) \\
\hline \multicolumn{10}{|l|}{ Suspended organic matter } \\
\hline $\begin{array}{l}\text { Quantity } \\
\text { Net sedimentation rate }\left(\mathrm{cm} 100 \mathrm{yI}^{-1}\right)\end{array}$ & \multicolumn{2}{|c|}{0} & \multicolumn{2}{|c|}{10} & \multicolumn{2}{|c|}{$25-60(30)$} & \multicolumn{2}{|c|}{35} & $(2)$ \\
\hline $\begin{array}{l}\text { Quality } \\
\text { Chlorophyll a/TOC }\left(\mathrm{ng} \mathrm{mg}^{-1}\right)\end{array}$ & \multicolumn{2}{|c|}{10000} & \multicolumn{2}{|c|}{2000} & \multicolumn{2}{|c|}{15000} & \multicolumn{2}{|c|}{500} & (4) \\
\hline Sediment & S & $\mathrm{D}$ & $\mathrm{S}$ & $\mathrm{D}$ & $\mathrm{S}$ & $\mathrm{D}$ & $\mathrm{S}$ & $\mathrm{D}$ & \\
\hline Median grain size $(\mu \mathrm{m})$ & 265 & 248 & 36.6 & 82.6 & 16.2 & 31.3 & 12.6 & 11.5 & (1) \\
\hline Silt + clay $($ particles $<50 \mu \mathrm{m})(\%)$ & 1.4 & 1.3 & 52.5 & 38.6 & 88.6 & 67.4 & 97.6 & 93.2 & (1) \\
\hline Fine sand (particles $50-113 \mu \mathrm{m})(\%)$ & 1.5 & 1.6 & 24 & 26.2 & 9.4 & 28.8 & 2.3 & 0.9 & (1) \\
\hline \multicolumn{10}{|l|}{ Quantity } \\
\hline $\operatorname{TOC}\left(\mathrm{mg} \mathrm{g}^{-1}\right)$ & 0.44 & 0.45 & 6.1 & 5.0 & 23.0 & 10.0 & 22 & 23 & (1) \\
\hline $\mathrm{TN}\left(\mathrm{mg} \mathrm{g}^{-1}\right)$ & 0.09 & 0.09 & 0.56 & 0.43 & 2.6 & 0.8 & 2.1 & 2.3 & (1) \\
\hline \multicolumn{10}{|l|}{ Quality } \\
\hline$\%$ EHAA-THAA $(\%)$ & \multicolumn{2}{|c|}{50} & \multicolumn{2}{|c|}{28} & & & & & (5) \\
\hline $\mathrm{C} / \mathrm{N}$ (molar ratio) & 4.6 & 6.0 & 13.0 & 13.5 & 15.5 & 12.1 & 12.1 & 11.8 & (1) \\
\hline Chlorophyll a ( $\left.\mu \mathrm{g} \mathrm{g}^{-1}\right)$ & & & & & 10.7 & 2.4 & & & (1) \\
\hline Bacterial biomass $\left(\mathrm{g} \mathrm{C} \mathrm{m}^{-2}\right)$ & & & & & & & & & (3) \\
\hline
\end{tabular}


ine input. These conditions result in intense algal blooms and an extremely high net input of labile organic matter into the sediment. The strong variations of current speed during a tidal cycle result in an alternation of particle settlement and resuspension (Boon \& Duineveld 1996). The upper sediment layer at the GB station has a high chlorophyll a content, probably originating from recent deposition. The organic matter concentration is also high in the top sediment layer and steeply decreases with depth. Degradabilities in the 0 to $1 \mathrm{~cm}$ surface and deeper sediment layers are different (Table 1).

Skagerrak: The total supply of organic carbon to the sediment is highest in the deepest depositional area (Skagerrak), where flow velocities are low. Compared to the high sedimentation rate, the carbon flux obtained by a sediment trap is very low, indicating an important horizontal input of refractory organic matter to this system. At SK sediment organic matter is refractory and has a low nutritional quality due to the strong dilution of the degradable fraction with refractory material (Dauwe \& Middelburg 1998) The high input of refractory organic matter leads to sediments with a high organic loading ( $2 \%$ TOC) but low quality (Table 1).

Macrofauna sampling and classification. At each station position, water depth, salinity and temperature of the bottom water were measured with a conductivity-temperature-depth profiler (CTD) and 2 to 4 cylindrical Reineck type box cores (diameter $31 \mathrm{~cm}$, maximum penetration depth $50 \mathrm{~cm}$ ) were collected (BF: 3 cores, FF: 4 cores, GB:3 cores, SK: 2 cores). On deck whole cores were sectioned into 4 depth strata $(0-2$, $2-5,5-10$ and $10-20 \mathrm{~cm}$ ). Each core section was gently sieved through a $50 \times$ $50 \mathrm{~cm}$ screen made of $500 \mu \mathrm{m}$ mesh size stainless steel. The residue retained on the sieve was stained with Rose Bengal and preserved in 5\% buffered formaldehyde in sea-water. All subsamples were preserved separately and the fauna was identified to species or family level under a binocular microscope. Bio-
Table 2. Biomass and abundance ( \pm standard error) of the most dominant species at the North Sea sample sites. $B=$ bivalves, $\mathrm{P}=$ polychaetes, $\mathrm{C}=$ crustaceans, $E=$ echinoderms, $O=$ other taxa. Feeding categories: $D F=$ subsurfacedeposit feeders, $\mathrm{SD}=$ surface-deposit feeders, IF = interface feeders, SF: suspension feeders, $O P=$ omnivores-predators. Less frequent, alternative feeding modes are given in parentheses. Bioturbation categories: DIFF = diffusive mixing (mostly free-living polychaetes, subsurface-deposit feecters and carnivores) and free-living (burrow excavating) crustaceans; SURF = surface deposition (mostly filter- and surface-deposit feeding tubicolous polychaetes and sedentary bivalves); $R E V=$ reverse conveyor belt transport ${ }_{i} \mathrm{CON}=$ conveyor belt transport. AFDW: ash-free dry weight

\begin{tabular}{|c|c|c|c|c|c|}
\hline & & Feeding & $\begin{array}{l}\text { Biotur- } \\
\text { bation }\end{array}$ & $\begin{array}{l}\text { Density } \\
\left(\text { no. } \mathrm{m}^{-2}\right)\end{array}$ & $\begin{array}{c}\text { Biomass } \\
\text { (g AFDW m }{ }^{-2}\end{array}$ \\
\hline \multicolumn{6}{|l|}{ Broad Fourteens } \\
\hline Echinocardium cordatum & $\mathrm{E}$ & $\mathrm{DF}(\mathrm{SD})$ & DIFF & $419 \pm 346$ & $0.36 \pm 0.22$ \\
\hline Amphipoda & C & IF & SURF & $1197 \pm 157$ & $0.12 \pm 0.02$ \\
\hline Total & & & & $2361 \pm 690$ & $1.8 \pm 0.6$ \\
\hline \multicolumn{6}{|l|}{ Frisian Front } \\
\hline Abra alba & B & $\mathrm{SD}$ & SURF & $1020 \pm 500$ & $2.26 \pm 1.6$ \\
\hline Mysella bidentata & B & SF & $?$ & $714 \pm 411$ & $0.07 \pm 0.03$ \\
\hline Nucula nitidosa & $\mathrm{B}$ & DF & DIFF & $25 \pm 16$ & $0.01 \pm 0.01$ \\
\hline Pectinaria koreni & $\mathrm{P}$ & $\mathrm{DF}(\mathrm{SD})$ & CON & $203 \pm 108$ & $0.43 \pm 0.31$ \\
\hline Spio sp./Polydora sp. & $\mathrm{P}$ & $\mathrm{SD}(\mathrm{SF})$ & SURF & $80 \pm 57$ & $0.02 \pm 0.02$ \\
\hline Chaetopterus variopedatus & $\mathrm{P}$ & $\mathrm{SF}$ & SURF & $7 \pm 12$ & $1.59 \pm 2.7$ \\
\hline Amphiura sp. & $\mathrm{P}$ & $\operatorname{IF}(O P)$ & SURF & $435 \pm 256$ & $2.09 \pm 1.0$ \\
\hline Callianassa subterranea & $\mathrm{P}$ & DF & DIFF & $141 \pm 29$ & $3.43 \pm 1.1$ \\
\hline Upogebia deltaura & $\mathrm{P}$ & $\mathrm{SF}$ & SURF & $27 \pm 15$ & $0.36 \pm 0.32$ \\
\hline Phoronis sp. & O & $\mathrm{SF}$ & SURF & $90 \pm 81$ & $0.03 \pm 0.04$ \\
\hline Total & & & & $3435 \pm 752$ & $13.5 \pm 5.6$ \\
\hline \multicolumn{6}{|l|}{ German Bight } \\
\hline Nucula nitidosa & B & DF & DIFF & $3347 \pm 1317$ & $7 \quad 5.80 \pm 2.4$ \\
\hline Abra alba & B & $\mathrm{SD}$ & SURF & $3233 \pm 1098$ & $88.60 \pm 5.4$ \\
\hline Ensis directus & B & $\mathrm{SF}$ & SURF & $3087 \pm 2390$ & $0 \quad 3.11 \pm 24$ \\
\hline Spisula subtruncata & B & $\mathrm{SF}$ & SURF & $3045 \pm 990$ & $2.55 \pm 2.0$ \\
\hline Mysella bidentata & $B$ & $\mathrm{SF}$ & $?$ & $250 \pm 63$ & $0.07 \pm 0.03$ \\
\hline Owenia fusiformis & $\mathrm{P}$ & IF & SURF & $2905 \pm 688$ & $9.69 \pm 7.8$ \\
\hline Spiophanes bombyx & $\mathrm{P}$ & IF & SURF & $863 \pm 410$ & $0.26 \pm 1.5$ \\
\hline Ophiura texturata & $\mathrm{E}$ & $O P(S F, S D)$ & SURF & $872 \pm 474$ & $1.61 \pm 0.4$ \\
\hline Caprella linearis & $\mathrm{C}$ & ? & ? & $688 \pm 203$ & $0.02 \pm 0.01$ \\
\hline Phoronidae & $\mathrm{O}$ & SF & SURF & $424 \pm 215$ & $0.10 \pm 0.08$ \\
\hline Total & & & & $20506 \pm 4645$ & $5 \quad 38.1 \pm 22$ \\
\hline \multicolumn{6}{|l|}{ Skagerrak } \\
\hline Thyasira flexuosa & B & DF & DIFF & $2305 \pm 141$ & $0.61 \pm 0.19$ \\
\hline Abra nitida & B & $\mathrm{SD}$ & SURF & $2043 \pm 120$ & $1.23 \pm 0.49$ \\
\hline Paramphinome jeffreysii & $\mathrm{P}$ & OP & DIFF & $2948 \pm 375$ & $0.37 \pm 0.054$ \\
\hline Tharyx sp. & $\mathrm{p}$ & $\mathrm{SD}$ & REV & $1867 \pm 127$ & $0.31 \pm 0.003$ \\
\hline Euclymene sn. Maldane sp. & $P$ & DF & CON & $1131 \pm 268$ & $1.35 \pm 0.37$ \\
\hline Ophelia rathkei & $\mathrm{P}$ & DF & DIFF & $983 \pm 71$ & $0.05 \pm 0.007$ \\
\hline Pholoesp./Harmothoesp. & $P$ & OP & DIFF & $629 \pm 516$ & $0.07 \pm 0.02$ \\
\hline Heteromastus filiformis & $\mathrm{P}$ & DF & CON & $502 \pm 35$ & $0.69 \pm 0.25$ \\
\hline Terebellides sp. & $\mathrm{P}$ & $S D$ & SURF & 495 & 0.32 \\
\hline Scoloplos sp. ${ }^{\mathrm{A}}$ & $\mathrm{P}$ & DF & CON & 438 & 0.78 \\
\hline Amphitrite sp. & $\mathrm{P}$ & $\mathrm{SD}$ & SURF & $354 \pm 71$ & $2.22 \pm 0.6$ \\
\hline Aphrodita aculeatad & $\mathrm{P}$ & $O P$ & DIFF & 240 & 0.02 \\
\hline Cumacea & $\mathrm{C}$ & $\mathrm{SD}(\mathrm{DF})$ & DIFF & $771 \pm 134$ & $0.09 \pm 0.03$ \\
\hline Oligochaeta & 0 & $\mathrm{DF}$ & DIFF & $1895 \pm 14$ & $0.05 \pm 0.008$ \\
\hline Total & & & & $21153 \pm 1216$ & $6 \quad 11.7 \pm 1.10$ \\
\hline
\end{tabular}

aspecies encountered in only one of the cores 
mass of each species/family was measured by weight loss after combustion at $500^{\circ} \mathrm{C}$. Tubicolous polychaetes were removed from their tubes prior to combustion.

The trophic status of each species/family was assigned by classification into feeding groups using information from the literature (Fauchald \& Jumars 1979, Barnes 1982, Jangoux \& Lawrence 1982) (Table 2). The trophic groups were defined on the basis of the food source and included suspension feeders, interface feeders (capable of alternative suspension- and surface-deposit feeding dependent on flow conditions, e.g. Taghon \& Greene 1992), surface-deposit feeders, subsurface-deposit feeders and omnivores/predators. Species which feed by more than 1 mode were classified by their most common feeding mechanism. Unidentified specimens and species for which only conflicting or no information about their major feeding mode exists were grouped together in the category 'unknown'.

The fauna was divided into 4 bioturbation categories. 'Diffusive mixing' describes vertical bioturbation as a diffusive transport process (Boudreau 1986a) with a 1-dimensional biodiffusivity that tends to smoothen tracer profiles and quickly redistributes fresh organic material within the sediment. 'Surface deposition' describes defecation of particles at the sediment surface (Jahnke et al. 1986). 'Conveyor belt transport' describes the translocation of sediment during subsurface-deposit feeding or burrow excavation. from some centimetres depth within the sediment up onto the surface. This process results in a downward, gravitationally forced, return of particles (Rhoads 1974 , Boudreau 1986b). 'Reverse conveyor belt transport' describes the downward movement of particles from the surface to some depth by feeding and defecation (Smith et al. 1986, Wheatcroft et al. 1994). In contrast to the conveyor belt mixing process, there is no return of the particles to the surface.

Sedimentary organic carbon. Organic carbon (TOC) was analyzed on finely powdered freeze-dried sediment samples. A 20 to $50 \mathrm{mg}$ split was combusted at $1010^{\circ} \mathrm{C}$ in a Carlo Erba Elemental Analyser NA-1500 after removal of carbonate by in situ acidification with $25 \% \mathrm{HCl}$ within silver sample cups (Nieuwenhuize et al. 1994). Reproducibility is about $2 \%$.

Diagenetic model. Berner (1980) describes the distribution of organic matter in the sediment using a model based on the deposition of fresh organic matter at the surface and the subsequent burial and down-mixing of the material while undergoing degradation. This model combines the interaction of the deposition and the decomposition processes, which causes enrichment, and the biogenic mixing process, which vertically homogenises the sediment and hence restrains surface enrichment of organic matter.
In order to investigate the possible effect of bloturbation by diffusive mixing on organic carbon mineralization deep in the sediment, we constructed a simple analytical model of a 2-layer sediment, subjected to constant sediment accumulation and with diffusionlike bioturbation confined to the upper layer and with a depth-independent bioturbation coefficient. Organic matter mineralization was modelled as a first-order process of organic matter concentration, with a depthindependent rate (Berner 1980). It was assumed that organic matter flux to the sediment surface is constant over time. The model was defined with the following equations:

Surface layer $(0 \leq x \leq L) \quad \frac{\partial C}{\partial t}=D_{b} \frac{\partial^{2} C}{\partial x^{2}}-\omega \frac{\partial C}{\partial x}-k C$

Deep layer $(x \geq L) \quad \frac{\partial C}{\partial t}=-\omega \frac{\partial C}{\partial x}-k C$

where $C=$ concentration of organic matter, $D_{b}=$ diffusive mixing (bioturbation) coefficient, $\omega=$ advection rate, $k=$ first-order degradation rate of organic matter, assuming a constant flux-boundary condition $F_{S}$ at $x=$ 0 , continuity of concentration $\left(C_{L}\right)$ and flux at $x=L$ and a no-flux condition at infinite depth. The model results for the mineralization rate at depth ( $\mathrm{mmol} \mathrm{C} \mathrm{cm}^{-3} \mathrm{yr}^{-1}$ ) at steady-state are shown for the following values of the parameters: $F=1 \mathrm{mmol} \mathrm{C} \mathrm{cm}^{-2} \mathrm{yr}^{-1}, L=20 \mathrm{~cm}, \omega=$ $1 \mathrm{~cm} \mathrm{yr}^{-1}$.

\section{RESULTS}

\section{Sediment characteristics}

There were clear differences in median grain size, silt content, oxygen penetration depth and biogenic activity between the sample sites (Table 1). The BF sediment consisted of coarse-grained sand, mixed with shell gravel. The oxygen penetration depth was high ( $>5 \mathrm{~cm}$ ), but there were no visible signs of bioturbation or animal activity.

The sediment at GB was fine-grained, black and highly sulfidic, with a fluffy upper layer. Tubes of the polychaete Owenia fusiformis extended some millimeters above the surface and reached up to 10 to $15 \mathrm{~cm}$ depth within the sediment. There were no visible signs of burrow openings or large feeding voids

In contrast, the FF sediment had a brown color and there were obvious signs of extensive bioturbation including numerous burrow openings and excavation mounds created mainly by the thalassinid shrimp Callianassa subterranea, and even larger burrows created by Upogebia deltaura and Chaetopterus variopedatus. Sediments were oxygenated along the linings of these burrows up to depths of $>25 \mathrm{~cm}$ within the sediment. 
The SK sediment was fine grained and had a yellowbrownish color. Obvious signs of animal activity were the tubes of Ampharetidae, which protruded up to $1 \mathrm{~cm}$ above the surface and extended $>20 \mathrm{~cm}$ deep into the sediment. The oxygen penetration depth was ca $5 \mathrm{~mm}$ between the tubes and 10 to $20 \mathrm{~cm}$ along the oxygenated tube linings.

\section{Total biomass, density and mean individual weight}

The vertical macrofauna biomass profiles were positively correlated with the TOC distribution in the sedi-
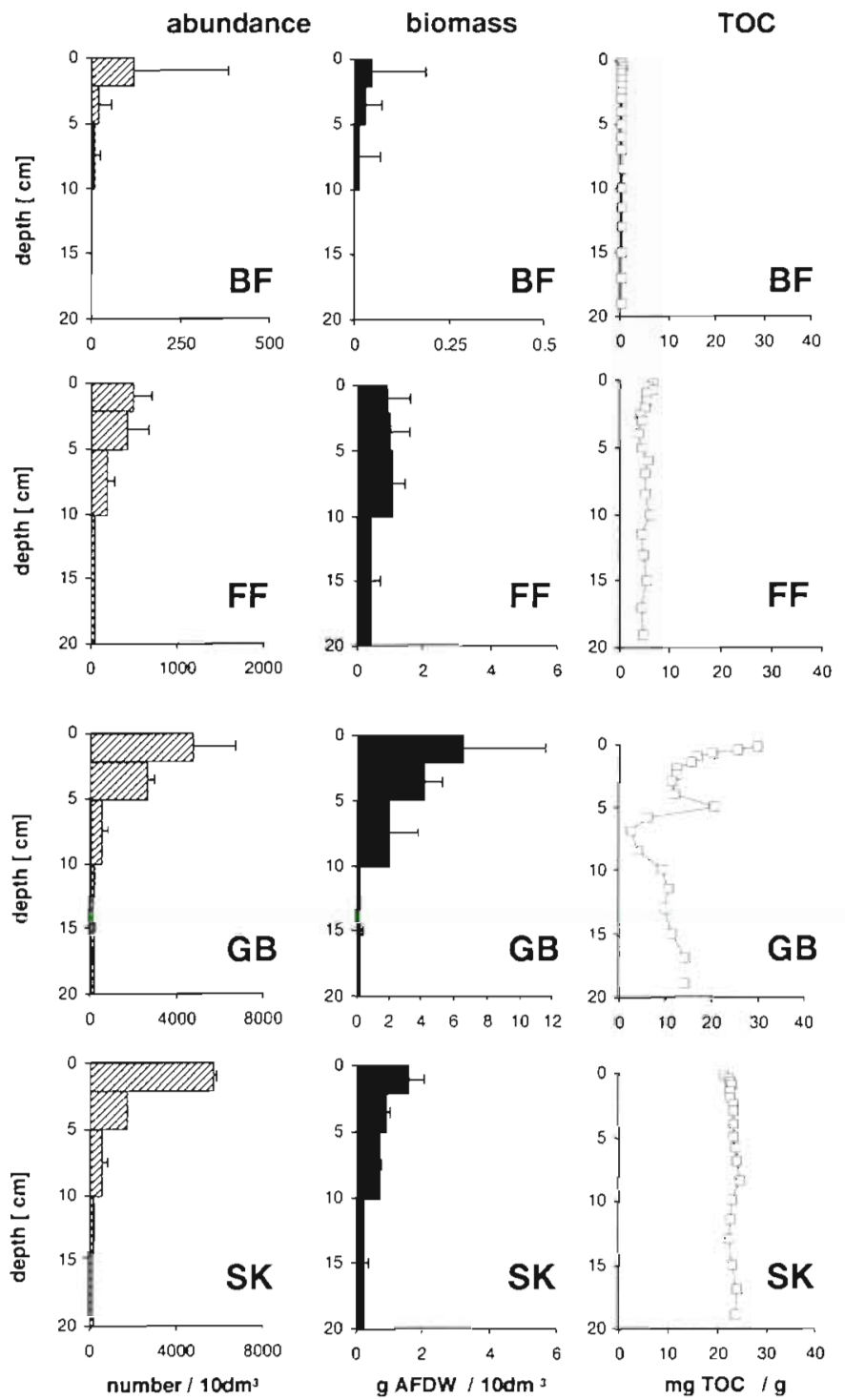

Fig. 2. Vertical distribution of macrofauna numbers ( \pm standard error), biomass ( \pm standard error) and total urganic carbon (TOC) profiles within the sediment. AFDW: ash-free dry weight. Station abbreviations as in Fig. 1
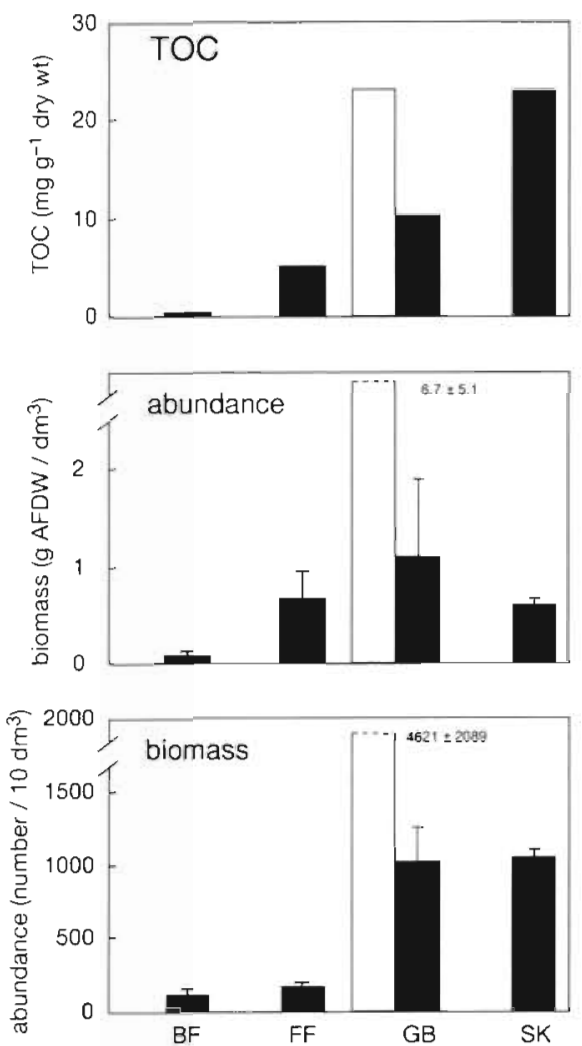

Fig. 3. Total organic carbon (TOC) content, macrofauna biomass and abundances ( \pm standard error) of the 0 to $20 \mathrm{~cm}$ sediment depth interval. Because of the heterogeneous profile at $\mathrm{GB}$, we distinguish the 0 to $2 \mathrm{~cm}$ surface layer (white bar) from the deeper 2 to $20 \mathrm{~cm}$ layers. Station abbreviations as in Fig. 1

ments (Fig. 2). At BF mainly the upper strata down to $5 \mathrm{~cm}$ depth were colonized by macrofauna. At FF abundance and biomass stayed nearly constant in the upper $10 \mathrm{~cm}$ and decreased only weakly deeper down. At GB the vertical distribution of macrofaunal biomass and abundance showed a steeply decreasing gradient. Most of the animals were restricted to the upper $5 \mathrm{~cm}$. There was only a weak decrease in organism density with depth. The biomass of the SK macrofauna decreased very slightly with increasing depth; however, the numerical abundance decreased very strongly.

Total biomass and abundance increased with increasing TOC content in the sediment; only SK had a relatively low biomass compared to the high organic carbon content of the sediment (Fig. 3). GB had a biomass 3 times higher than the other 2 sites with finegrained sediments (FF and SK). At the BF station biomass of macrobenthos was extremely low (Fig, 3, Table 1).

The trend in abundance was somewhat different. Maximal densities of $\sim 20000$ ind $\mathrm{m}^{-2}$ were found at $G B$ and SK respectively, whereas FF and BF had rela- 


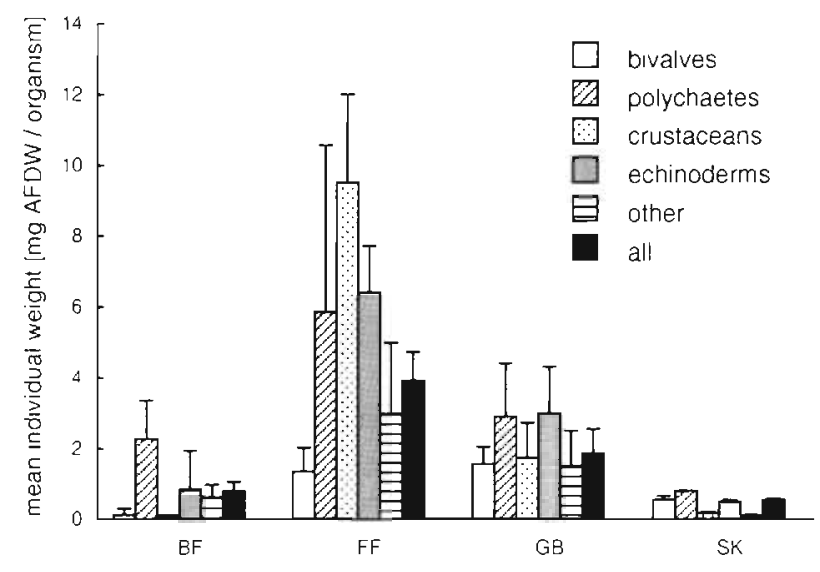

Fig. 4. Mean individual weight ( \pm standard error) of major taxa and total macrofauna. Station abbreviations as in Fig. 1

tively low abundances of $\sim 2500$ to 3500 ind. $\mathrm{m}^{-2}$ (Fig. 3 , Table 2). At FF, the mean individual weight of about $4 \mathrm{mg}$ ash-free dry weight (AFDW) organism ${ }^{-1}$ was very high (Fig. 4). Larger animals were also found at the GB station ( $2 \mathrm{mg} \mathrm{AFDW} \mathrm{organism} \mathrm{m}^{-1}$ ). At the SK station the organisms were small with a mean individual weight of only $0.5 \mathrm{mg}$ AFDW organism ${ }^{-1}$ (Fig. 4).

\section{Vertical distribution of major taxa and dominant species}

\section{Broad Fourteens}

The upper 0 to $2 \mathrm{~cm}$ surface layer was dominated by juvenile sea urchins Echinocardium cordatum (Fig. 5a); in deeper layers polychaetes dominated (Fig. 6a).

\section{Frisian Front}

Bivalves dominated the upper strata, whereas crustaceans were concentrated in the deeper layers (Fig. 6b). Abra alba and Mysella bidentata were the dominant bivalve species, together contributing $>90 \%$ of the total biomass and total numbers. Individuals of $M$. bidentata were generally very small, and therefore less dominant in terms of biomass (Table 2). Both species reached high abundances even at $10 \mathrm{~cm}$ depth (Fig. 5b, c). M. bidentata lives in Amphiura filiformis burrows (Ockelmann \& Muus 1978) and showed a peak of biomass and abundance at 2 to $5 \mathrm{~cm}$ depth (Fig. 5c) coinciding with the A. filiformis peak (echinoderm in Fig. 6b).

The contribution of polychaetes to total biomass was constant with depth, varying between 20 and $40 \%$ (Fig. 6b) and diversity was very high (consisting of $>21$ families). The most important species in terms of numbers was Pectinaria koreni (Table 2), with maximum densities in the 2 to $5 \mathrm{~cm}$ subsurface layer (Fig. 6d). Most important in terms of biomass was the large polychaete Chaetopterus variopedatus ( $\pm 15 \mathrm{~cm}$ body length) that was found only below $10 \mathrm{~cm}$ depth (Fig. 5e).

The increasing biomass share of crustaceans with increasing sediment depth (Fig. 6b) was due to the occurrence of large-sized species such as the thalassinid shrimps Callianassa subterranea and Upogebia deltaura (Table 2). C. subterranea showed an increasing density up to the $5-10 \mathrm{~cm}$ depth interval and even in the 10-20 cm layer the density was very high (Fig. 5f). Upogebia sp. is too large and too deep-living $(10-30 \mathrm{~cm})$ to be quantitatively estimated by box coring. Amphipods were numerically important, contributing up to $40 \%$ of the total crustacean numbers, but only to $2 \%$ of total biomass and are generally restricted to the surface layer of the sediment (data not shown).

\section{German Bight}

Small bivalves (Fig. 4), dominated the upper 0 to $5 \mathrm{~cm}$ surface layer, contributing more than $70 \%$ to the total macrofaunal biomass in the upper sediment layers (Fig. 6c). Four species, Alba alba Spisula subtruncata, Ensis directus and Nucula nitidosa, contributed nearly evenly to the bulk of the bivalve biomass (Table 2). A. alba, S. subtruncata and E. directus showed very similar depth distribution patterns, with strongly declining biomass with increasing sediment depth (Fig. 5g-i). In contrast, $N$. nitidosa, a species tolerant to anoxic conditions, showed a 3-fold increase in biomass from about $0.5 \mathrm{~g} \mathrm{AFDW} \mathrm{dm}^{-3}$ at the surface to nearly $0.15 \mathrm{~g} \mathrm{AFDW} \mathrm{dm}^{-3}$ at 2 to $5 \mathrm{~cm}$ depth (Fig. $5 \mathrm{j}$ ).

With increasing depth below $5 \mathrm{~cm}$, the importance of bivalves dropped sharply and polychaetes took over. They contributed 70 to $80 \%$ to the total biomass at depths of 10 to $20 \mathrm{~cm}$ (Fig. 6c). Polychaete diversity was much lower than at FF and SK, consisting of only 14 families. The predominant species was the large tubicolous polychaete Owenia fusiformis, contributing $58 \%$ to the total numbers and $73 \%$ to the total biomass of polychaetes at all depths (Table 2). O. fusiformis is a deep-living species and showed a 20 -fold increase in biomass with increasing sediment depth, up to about $10 \mathrm{~cm}$ depth (Fig. 5k). Spiophanes bombyx was numerically important, contributing to $18 \%$ of the total number of polychaetes (Table 2), but was not relevant in terms of biomass.

Echinoderms and crustaceans generally contributed little to the total biomass. Only the 0 to $2 \mathrm{~cm}$ surface stratum was populated by echinoderms (Fig. 6c). The main species was the brittle star Ophiura texturata (Fig. 5l). 
Skagerrak

Polychaetes clearly dominated the fauna at this site and had a high diversity (consisting of $>27$ families). With increasing depth into the sediment their share in the biomass increased (Fig. 6d), due to the increasing dominance of large, tube-inhabiting, species. Important in terms of biomass and numbers were the tubeliving families Maldanidae (mainly Euclyme sp. and Maldane sp.) and Ampharetidae (Table 2), which
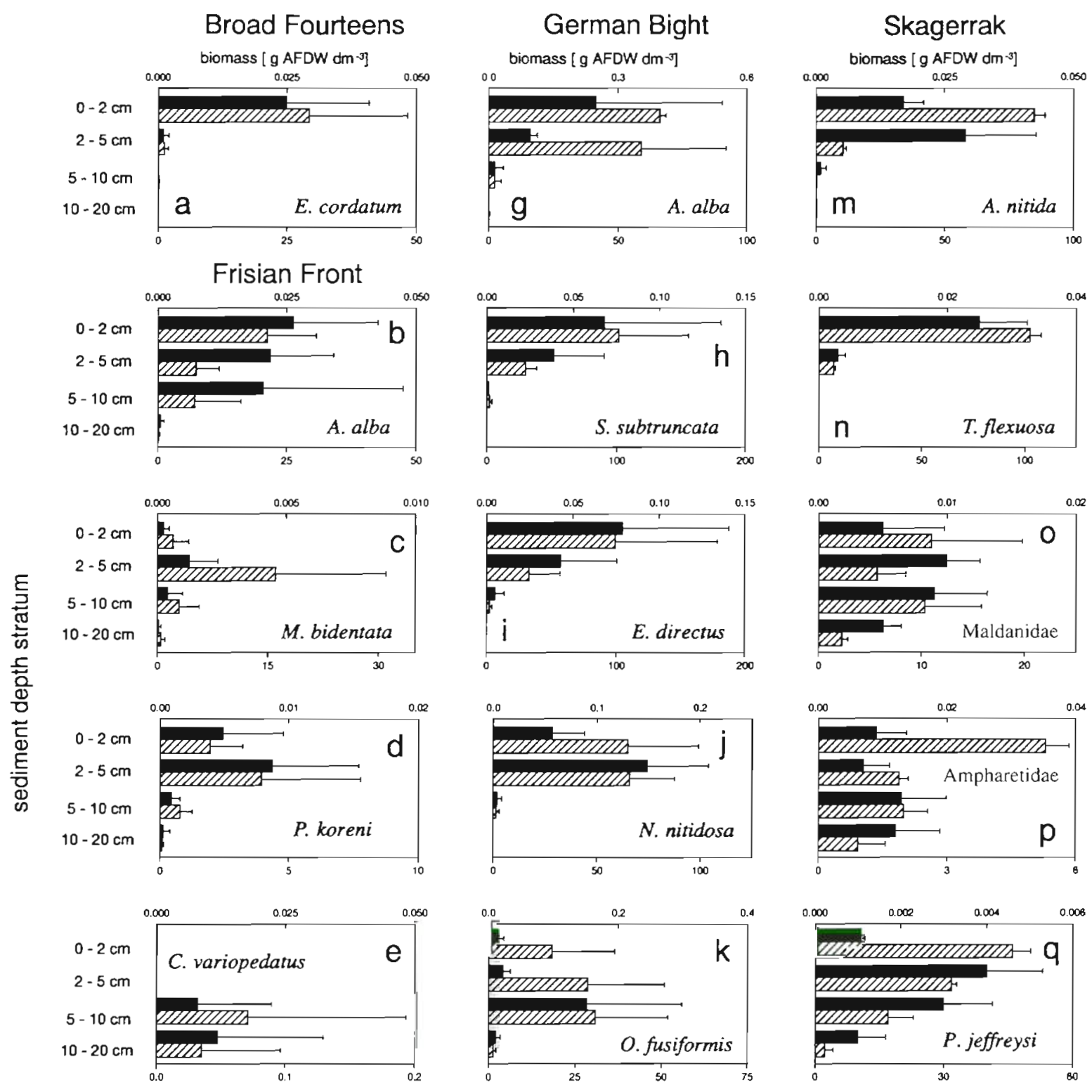

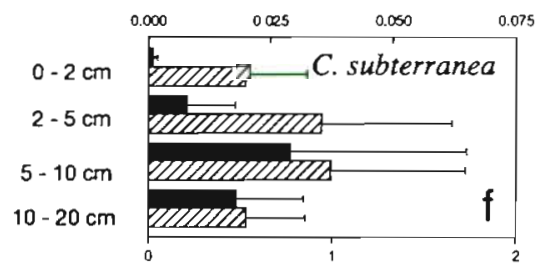

abundance [number $\mathrm{dm}^{3}$ ]

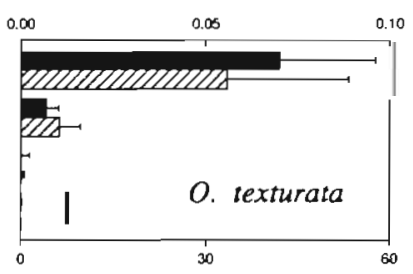

abundance [number $\mathrm{dm}^{3}$ ]

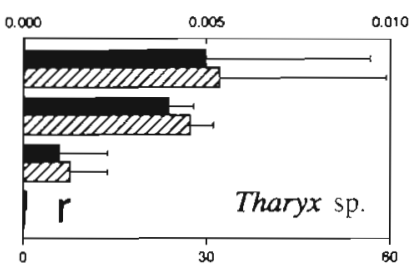

abundance [number $\mathrm{dm}^{3}$ ]

Fig. 5. Numerical and biomass distribution ( \pm standard error) of the most dominant species within the sediment. Black bars: biomass; cross-hatched bars: abundance. See Table 2 for full species names 
showed a homogeneous depth distribution (Fig. 5o, p). The biomass profile of the numerically important omnivore/predatory species Paramphinome jeffreysi showed a subsurface peak at 2 to $10 \mathrm{~cm}$ depth (Fig. $5 \mathrm{q}$ ). The small species Tharyx sp. was most abundant in the upper $5 \mathrm{~cm}$ (Fig. $5 \mathrm{r}$ ).

Bivalves were the second most important group, with a subsurface biomass peak in the 2 to $5 \mathrm{~cm}$ interval (Fig. 6d). The contribution to total numbers also decreased with increasing sediment depth, reaching nearly $40 \%$ in the upper stratum and less than 10\% in the deepest stratum. Three species contributed to $>90 \%$ of this group. Abra nitida and Thyasira flexuosa showed a very shallow depth distribution, limited to the upper 0 to $2 \mathrm{~cm}$ stratum (Fig. $5 \mathrm{~m}, \mathrm{n}$ ), but Nucula sp. inhabited deeper strata with maximum densities in the 5 to $10 \mathrm{~cm}$ stratum

\section{Trophic groups}

Fig. 7 shows the relative importance of the different trophic groups in terms of biomass. Density contributions generally gave the same results and therefore are not presented here. At BF, deposit feeders were the most important group, with the sea urchin Echinocardium cordatum as the main contributor. Suspension feeders were absent. Only a small percentage of the total biomass was formed by surface-deposit feeders (mainly Magelonidae) and interface feeders (mainly Amphipods). The group omnivores/predators was formed by a few, very large polychaetes (e.g. Nepthys sp.).
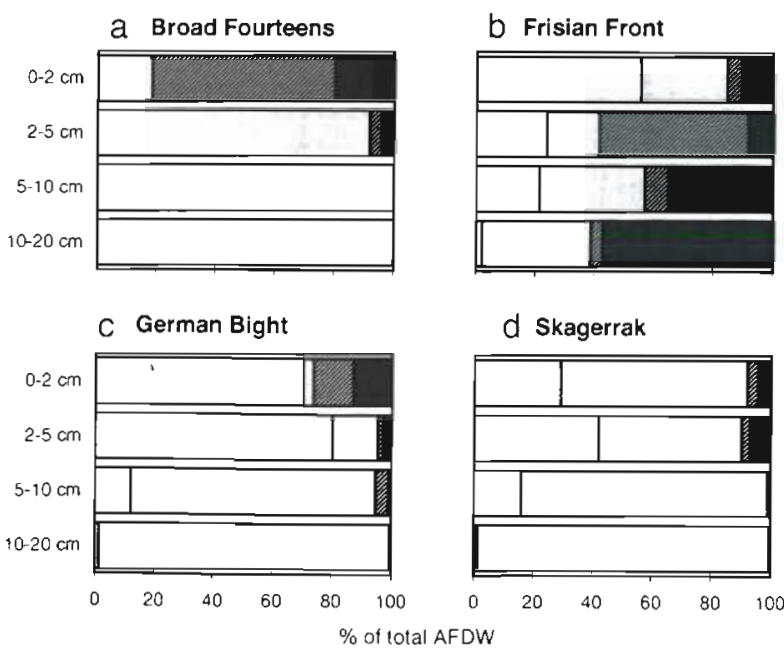

BIVALVES

POLYCHAETES

ECHINODERMS

Fig. 6. Vertical distribution of the contribution major taxonomic groups to total biomass
At FF subsurface-deposit feeders were the largest group, but animals feeding at the sediment-water interface were also present. Subsurface-deposit feeders consisted of large burrow-excavating animals, mainly the thalassinid shrimp Callianassa subterranea and the polychaete Pectinaria koreni. Suspension feeders were mainly represented by the bivalve Mysella bidentata. Deep-living subsurface filter feeders were also present (e.g. the thalassinid shrimp Upogebia deltaura and the large polychaete Chaetopterus variopedatus). These species pump water through their U-shaped burrows and filter it for food particles. Interface feeders were represented by the brittle star Amphiura filiformis mainly. The bivalve Abra alba was the dominant surface-deposit feeder.

GB was characterized by the scarcity of subsurfacedeposit feeders. Most animals, such as surface-deposit feeders (mainly Nucula nitidosa and Abra alba), suspension feeders (mainly Ensis directus and Spisula subtruncata) and interface feeders (mainly Owenia fusiformis), fed near the sediment-water interface. Species from various taxa contributed to the omnivore/predator group, but most important was the epibenthic brittle star Ophiura texturata.

At SK no animals were feeding in the water column. The predominant feeding modes were surface-deposit feeders (Abra sp. and Tharyx sp.) and subsurfacedeposit feeders (oligochaetes, Maldanidae). Compared to the other stations the endobenthic omnivore/preda-
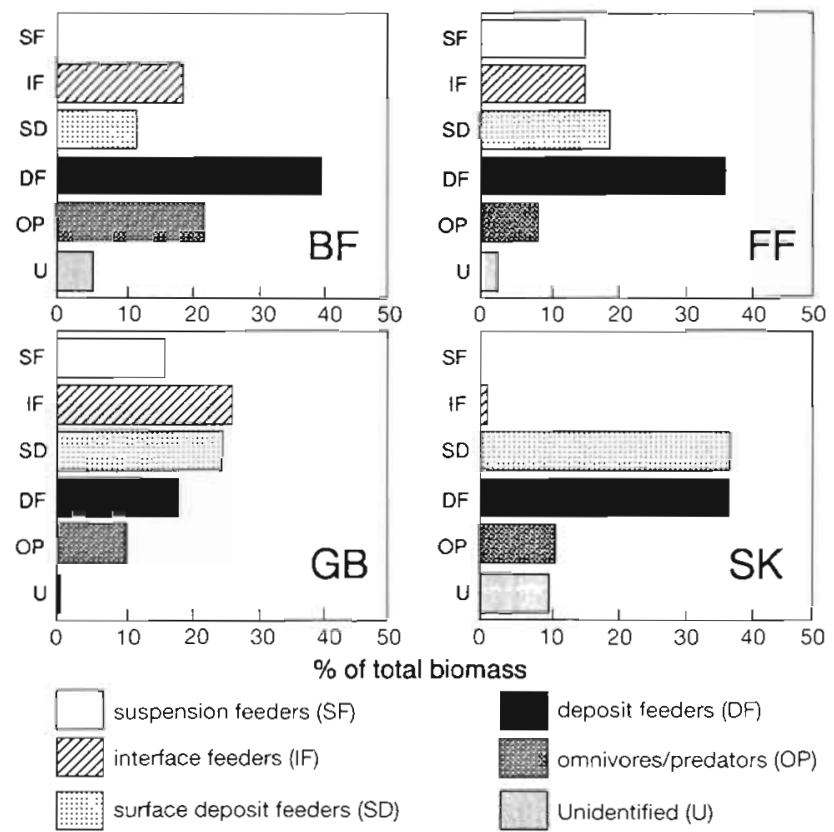

Fig. 7. Contribution of the trophic groups to total biomass. Trophic groups are arranged along an axis representing the level from which the food is taken by the organisms. Station abbreviations as in Fig. 1 
a

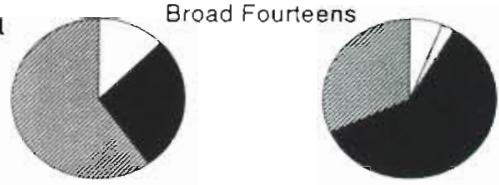

$\mathrm{b}$

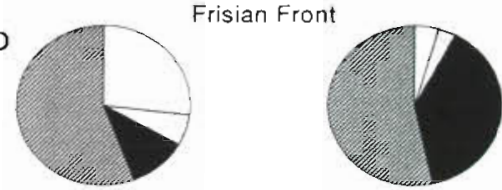

C
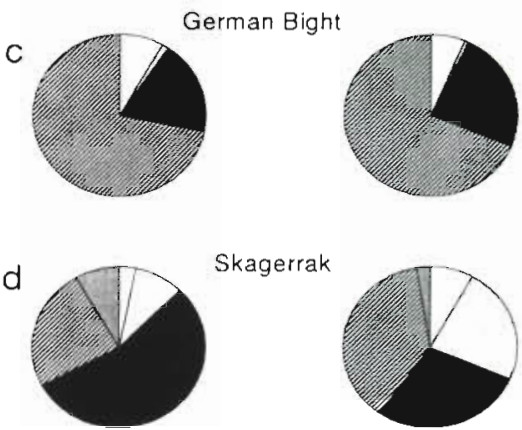

DENSITY

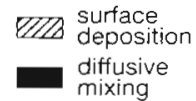

$\square$ conveyor belt transport
reverse conveyor belt

$\square$ unknown

Fig. 8. Contribution to the bioturbation categories as the percentage of total numbers and percentage of total biomass

tor group had the largest numerical abundance, consisting of the amphinomid polychaete Paramphinome jeffreysi. The small bivalve Thyasira flexuosa was categorized as a subsurface-deposit feeder. It depends indirectly on sedimentary organic matter through its symbiosis with chemoautotrophic sulfur bacteria in the gills (Dando \& Southward 1986).

\section{Bioturbation categories}

At BF, surface deposition was important in terms of density contribution, whereas diffusive mixing dominated the biomass contribution (Fig. 8a). The FF sediment was dominated by species belonging to the surface deposition category, but in terms of biomass contribution diffusive mixing was important (Fig. 8b). The station GB was clearly dominated by surface deposition, with nearly $75 \%$ of al. individuals and total biomass contributing to this category (Fig. 8c). At SK diffusive mixing was the most dominant bioturbation category in terms of numbers, but a small individual size of the species leads to a less important contribution to total biomass (Fig $8 \mathrm{~d}$ ). Conveyor belt

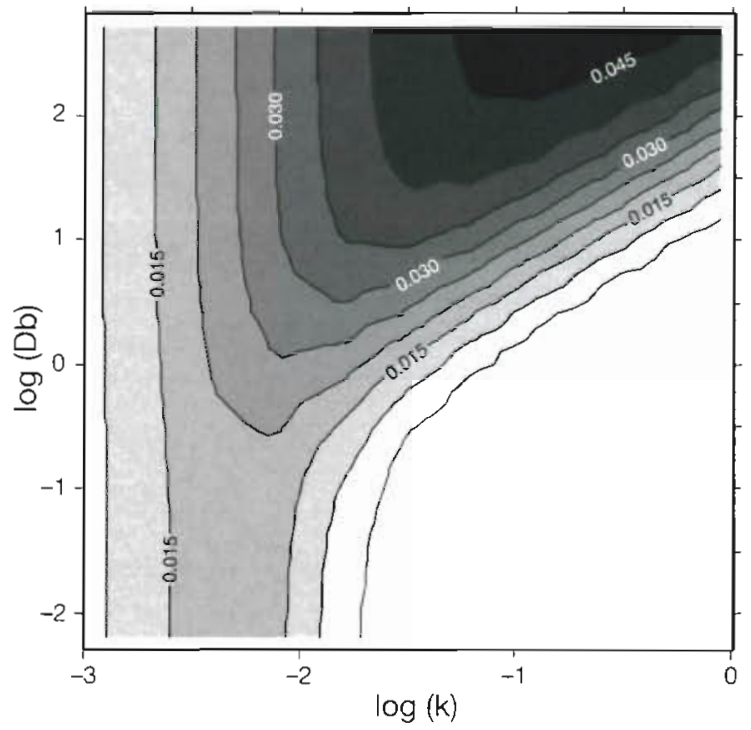

Fig. 9. Mineralization rate $\left(C_{L} \times k\right)$ at $20 \mathrm{~cm}$ depth in relation to the intensity of diffusive mixing (bioturbation rate $D_{b}$ ) and the quality of the arriving organic matter at the surface of the sediment $(k)$

transport occurred at all stations, but was not dominant. Reverse conveyor belt transport was absent at most investigated North Sea sediments (Fig. 8a-c); only at SK did the polychaete Tharyx sp. (Fig. 8d, Table 2) contribute to this category.

\section{Diagenetic model}

The model (Fig. 9) shows how the mineralization rate at $x=L$, given as $C_{L} \times k$, depends on the quality of the arriving material $(k)$ and the intensity of the diffusive mixing by bioturbation $\left(D_{b}\right)$. The absolute value of this mineralization was very much dependent on the value of $L$ chosen, but the relative dependence on $k$ and $D_{b}$ was very little influenced by it

For a given quality of arriving organic matter, the graph shows that mineralization rate of the organic matter at depth $x=L$ will always monotonically increase with bioturbation coefficient, but the increase is highly non-linear and depends on the quality of the arriving organic matter. When arriving organic matter is of low quality, there is hardly any increase in mineralization rate at depth with an increasing bioturbation coefficient. This implies that animals will not be able to increase their food source by increasing the bioturbation. When the arriving organic matter is of intermediate quality, the mineralization rate initially increases steadily and in large steps with an increasing bioturbation coefficient until a plateau is reached at which little rise in mineralization rate can be gained by additional bioturbation. When the arriving organic material is of. 
high quality, the mineralization at depth is influenced little by an increasing bioturbation coefficient until the latter becomes very high. The dependence is very steep and levels off at a high bioturbation rate. For a given bioturbation coefficient (along a horizontal line in Fig. 9), the mineralization rate at depth reaches an optimum at intermediate quality of the arriving organic matter. The optimal quality of the arriving organic matter increases with bioturbation rate, but rather slowly: a 100-fold increase in bioturbation coefficient causes about a 10 -fold increase in optimal quality.

\section{DISCUSSION}

A classical topic in benthic research is the relationship between abiotic factors and the structure of faunal communities. The 2 major ecological categorizations of benthos, based on functional associations of a community with the sedimentary habitat, are (1) trophic groups and (2) bioturbation modes. The first refers to how and where animals obtain food. The second refers to the displacement of sediment particles as a consequence of animal mobility and feeding.

The conventional view is that environmental constraints determine the community structure of the fauna. Sediment and flow characteristics, such as median grain size, silt content, bottom shear stress, etc., are clearly correlated with macrofaunal community structure (e.g. Heip \& Craeymeersch 1995). In addition, food supply seems to affect the trophic structure of the fauna (Snelgrove \& Butman 1994 and references therein). However, a faunal community, once established in a suitable area, will also change its geochemical environment by bioturbation. The redistribution of organic matter within the sediment by effective bioturbating species will influence depth distribution and community structure as well. In this section we will first highlight the contrasting abiotic factors at the North Sea stations that set the constraints for the communities and then discuss the influence of the fauna on the distribution of organic matter within the sediment.

\section{Trophic stucture in relation to food quality and abiotic factors}

This study demonstrates marked differences in vertical distribution (Fig. 2) and trophic groups (Fig. 5) of macrofauna at stations with contrasting food supply in the North Sea. The communities were site-specific and had only a few species in common (Fig. 6, Table 2). This is probably due to the large geographical distance between the stations, which enabled us to compare independent communities.

Categorisation of macrofauna into functional groups (based on trophic and bioturbation characteristics of the main species) implies drawbacks such as absent, unreliable or inconsistent species-specific auto-ecological information and behavioral modification which depends on environmental conditions (e.g. interface feeding). Spatfalls of dominant species (e.g. small Echinocardium cordatum at Stn BF) may also temporarily change the community structure in favor of a specific group. Nevertheless, a general categorisation is a useful approach to unraveling the mechanistic relationships between faunal community structure and sediment characteristics.

The North Sea stations have been investigated for bulk faunal biomass and composition on earlier cruises, without regarding vertical distribution. The general resemblance of our samples with those from previous studies (see the discussion below) indicates that our results show typical communities at these contrasting stations, despite the limited sample size.

At BF, the low content of organic matter in this coarse-grained sediment is reflected by an extremely low macrofaunal biomass (Fig. 3). Even though the relative quality of the organic matter is very high (Dauwe et al. in press), the total amount of available organic matter is probably too low to support a large benthic community. Despite the low food content in the sediment, there should be some scope for suspension feeders (Rhoads \& Young 1970) since strong tidal currents keep most of the organic particles in suspension. The horizontal supply of small and light nutritious particles by resuspension and advective transport has been shown to influence the growth rate of suspensionfeeding benthos. The actual scarcity of suspension feeders at this site (Fig 7) can be explained by the strong environmental stress that brings the upper sediment layer in suspension at high tide (Jenness \& Duineveld 1985) and consequently will inhibit larval settlement or erode settlers. The common assumption that suspension feeders are restricted to sandy habitats has been contradicted several times (e.g. Duineveld et al. 1987, who showed that Amphiura filiformis abundance is positively correlated with mud content). One reason for this is that not all filter feeders have a filter apparatus which is vulnerable to clogging by finegrained material. Suspension feeding bivalves with long slender siphons (e.g. Tellinacea) and tentacle feeding polychaetes often occur in muddy habitats and actually select for the smallest particles they encounter (Taghon et al. 1982).

At $F F$, the prolonged sedimentation of relatively fresh organic matter during frontal conditions will promote the growth of suspension and interface feeders in 
the first place, but extended deposition later in the season is beneficial to subsurface-deposit feeders as well. The high diversity of trophic groups (Fig. 5) indicates a stable and mature benthic system with little stress from organic pollution or hydrodynamic disturbances. Both are in agreement with the relatively low surface current speeds in this region (Table 1) and the favorable conditions of food supply (de Gee et al. 1991). The Amphiura filiformis-Mysella bidentata association (Ockelmann \& Muus 1978) and the subsurfacedeposit feeding shrimp Callianassa subterranea were important contributors to the macrofaunal community (Table 2). In a comparable boundary area between mixed and summer stratified water masses in the North Sea, the Oyster Grounds, Duineveld et al. (1987) and Creutzberg et al. (1984) reported high densities of C. subterranea (400 to 2000 ind. $\mathrm{m}^{-2}$ ). Values from FF are within this range, but the biomass was relatively low $\left(3.4 \mathrm{~g} \mathrm{AFDW} \mathrm{m}^{-2}\right.$ ) compared to values from the

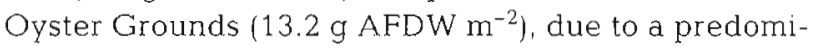
nance of juvenile individuals.

The deep burrowing (Fig. 3) by the large-sized macrofauna (Fig. 2) oxygenates the sediment down to a considerable depth. One individual of Amphiura filiformis can oxidize a surface of $35 \mathrm{~cm}^{2}$ to a depth of $3 \mathrm{~cm}$ in the sediment by extending its arms through the sediment to the sediment-water interface and by regular flushing of the feeding void with oxygen-rich water (Ockelmann \& Muus 1978). The subsurfacedeposit feeding Callianassa subterranea is known for its extraordinary strong bioturbation capacity (Branch \& Pringle 1987, Witbaard \& Duineveld 1989) and ability to oxygenate the sediment (Koike \& Mukai 1983, Dobbs \& Guckert 1988, Forster \& Graf 1995). The branched burrow systems of $C$. subterranea are continuously rebuilt and reach down to $80 \mathrm{~cm}$ into the sediment (Nickel \& Atkinson 1995), resulting in sediment turnover rates of up to $12 \mathrm{~kg} \mathrm{~m}^{-2} \mathrm{~d}^{-1}$. Thalassinedean shrimps have important effects on benthic community composition and are important key species in structuring the infaunal community (Posey 1986, Branch \& Pringle 1987). Their effect on the depth distributions of the macrofauna at FF is obvious: species inhabit specific depth strata (niches) in the sediment (Fig 6), which therefore is much more heterogeneous than at the other sites.

At GB, the strong seasonal input of extremely labile organic matter creates eutrophic conditions, as indicated by the highly anoxic sediments and the occurrence of a fluffy surface layer (Table 1). The fauna is well adapted to the strongly variable tidal. currents that resuspend the surficial organic matter. regularly (Boon \& Duineveld 1996). The predominant interface feeders are adapted to more variable food sources than subsurface-deposit feeders by changing their feeding strategy according to current flow conditions (Taghon 1980).

During the period 1975 to 1984, when eutrophication drastically increased in muddy habitats of the inner German Bight, opportunistic short-lived species with an adaptive feeding behavior became dominant; longlived species and many subsurface dwellers (such as Amphiura filiformis, Echinocardium cordatum and Nucula nitidosa) decreased (Rachor 1990).

The protobranch bivalves Nucula sp. are also known for their high tolerance against anoxia in the sediment (Taylor et al. 1995), enabling a successful colonization of eutrophicated areas such as the German Bight that are generally highly anoxic.

The deep SK station $(>300 \mathrm{~m}$ ) represents a very stable hydrographical environment, with negligible seasonal variation of current speed and water temperature (Josefson 1985) compared to the more dynamic shallow stations investigated in this survey. Most of the algal biomass produced in the water column is channelled through the pelagic microbial food chain and only a minor part eventually serves as food for the benthic system (Rosenberg et al. 1990). The bulk of the organic matter arrives by near-bottom horizontal transport and resuspension processes (van Weering et al. 1987, Stevens et al. 1996), creating a highly predictable constant supply to the benthos. In some areas, high accumulation rates on the slopes (up to $1.2 \mathrm{~cm} \mathrm{yr}^{-1}$; van Weering et al. 1987, 1993) lead to an additional downslope transport (Stevens et al. 1996). The sediment organic matter has the lowest nutritional quality of the 4 stations (Dauwe et al. in press). The relatively low macrofaunal biomass (Table 1) and the very small mean individual weight (Fig. 2), which contrast with the high organic matter input and high organic carbon. concentration and clay content of the sediment, are most probably due to this low food quality of the organic matter.

The faunal composition at our $280 \mathrm{~m}$ SK station resembles that of the ca $100 \mathrm{~m}$ deep stations in the 'Deep Trench' sampled by Rosenberg (1995) and the $260 \mathrm{~m}$ slope station in the 'Norwegian trench' (Rosenberg et al. 1996) in the southeastern Skagerrak, with the small polychaete Paramphinome jeffreysii and the bivalve Abra nitida being the most abundant species (Table 2). Rosenberg et al. (1996) recorded major divisions in species composition and trophic groups in different depth zones (slope and deep basin areas), which they attributed to differences in sedimentation rate and organic matter supply. Subsurface-deposit feeders had highest densities in the deep section (400 to $700 \mathrm{~m}$ ) of the 'Deep Trench', where the accumulation of organic matter is likely to be highest. Resuspensiondominated slope areas were strongly favoured by suspension feeders. The species composition and feeding 
groups at our SK station support the assumption that the $280 \mathrm{~m}$ deep SK sampling site is dominated by accumulation processes rather than by resuspension. The high accumulation of refractory organic allows for a rich fauna of subsurface-deposit feeding animals (Fig. 6) that are generally adapted to a remarkably poor food source (Lopez \& Levinton 1987). Subsurfacedeposit feeders overcome this restriction by either selective ingestion of particles rich in organic matter, effective absorption of limiting compounds or increased sediment processing rates (e.g. Taghon 1981 , 1982). Since nitrogen is generally limiting to growth (e.g. Tenore 1983), this limitation will be very evident in a refractory environment where the bioavailable amino acid fraction is highly diluted by a refractory nitrogen pool (Dauwe et al. in press). Possible mechanisms to fulfil the nutritional needs in refractory sediment may be predatory behaviour or symbiosis with chemoautotrophic bacteria (e.g. Thyasira sp.). Phillips (1984) showed that it is most beneficial for organisms to feed on living tissue, to maximise the intake of deficient essential amino acids from the sediment. The high numerical contribution of endobenthic predators (mainly Amphinomidae, Sigalonidae, Aphroditidae and other free-living polychaetes) to the fuanal community is striking (Table 2). Rosenberg et al. (1996) and Josefson (1985) also found an exceptionally high numerical contribution of predators (>20\%) at the 200 to $450 \mathrm{~m}$ deep Skagerrak slope stations.

We conclude that stations with comparably high bulk organic matter contents such as GB and SK, but different vertical distributions and nutritional qualities, have different trophic structures as well. The high amount-low quality sediments of SK are inhabited by a subsurface deposit feeder-dominated community with a homogeneous depth distribution consisting mainly of small organisms, whereas the high amount-high quality GB sediment which has a surface accumulation of organic matter was populated by a suspension-interface feeding community with a shallow depth distribution. The Pearson \& Rosenberg (1978) model would generally predict high abundances of shallow-living subsurface-deposit feeders at high organic loading, regardless of the nutritious quality and vertical distribution.

\section{Influence of bioturbation on the distribution of organic matter}

Although the community structure is obviously influenced by the amount, nutritional value and vertical distribution of organic matter, a faunal community once established in a certain area will modify its environment by bioturbation. The influence of the benthic community on particle displacement is demonstrated by its instantaneous reaction to pulsed inputs of fresh algal detritus to the sea-floor by consumption (Gooday \& Turley 1990, Pfannkuche 1993, Blair et al. 1996) and rapid burial with vertical velocities $>1 \mathrm{~cm} \mathrm{~d}^{-1}$ (Graf 1989). This bioturbation activity determines the fractionation, distribution and availability of the organic matter for the community.

The homogeneous depth profiles of macrofauna and TOC at SK and below the 0 to $1 \mathrm{~cm}$ zone also at FF (Fig. 2) suggest an effective diffusive mixing process of the surface-deposited organic matter. Diffusive mixing is mainly associated with mobile subsurface-deposit feeding or burrowing species and free-living predators (Table 2). The reason for the strong numerical contribution of the biodiffusion category at SK (Fig. 8) is that large numbers of small-sized free-living polychaetes (Fig. 4) are distributed deeply within the sediment (Fig. 6). The deep-living subsurface-deposit feeding bivalve Thyasira sp. (Fig. 5) is also known to affect sediment chemistry and organic matter distribution by bioturbation, thus strongly affecting the fate of the organic matter in this sediment. In contrast, in FF sediments the biodiffusion group consisted of large animals, reflected by the high biomass contribution of this group (Fig. 8). The most important species, Callianassa subterranea, has been documented to be an extremely effective bioturbator reaching very high sediment turnover rates of 3.5 to $11 \mathrm{~kg} \mathrm{~m}^{-2} \mathrm{yr}^{-1}$ (Witbaard \& Duineveld 1989, Rowden \& Jones 1993). On the basis of the Foraminifera record, Moodley (1990) found the FF sediments to be mixed up to $30 \mathrm{~cm}$ depth.

The most effective performers of conveyor belt transport are large tubicolous head-down deposit feeding polychaetes such as maldanids (Levin et al. 1997). capitellids and pectinarids (Table 2). This process was generally not abundant; only SK sediments were bioturbated this way $(10 \%$ of total number, $24 \%$ of biomass) mainly by maldanids (Euclymene sp., Maladane sp.), but also by capitellids Capitella capitata and orbiniids Scoloplos sp.

The station with the strongest predominance of surface deposition (GB) (Fig. 8) shows the strongest surface accumulation of organic matter (Fig. 3) and a predominance of the water interface-oriented feeding modes (Fig. 7). Many animals selectively ingest organically enriched particles (Self \& Jumars 1978) and, although organic matter is removed during gut-passage, the residual fecal material is still often enriched relative to bulk sediment (Hylleberg \& Galucci 1975, Jumars et al. 1981, Brown 1986). Again there is some linkage between feeding mechanism and dominant particle transport mode since most animals belonging to the category 'surface deposition' are surface-deposit feeders, suspension feeders or interface feeders 
(Table 2). Subsurface-deposit feeders are scarce at GB (only represented by Nucula sp.), and therefore there is little biogenic down-mixing of organic matter.

Also at FF, surface deposition is of considerable importance as well in terms of biomass as numbers, even though the accumulation effect is smoothed by the co-occurring biodiffusion species (see above) (Fig. 8). These results agree well with the finding that sediments containing marked surface enrichments of organic matter are often characterised by lack of bioturbation (i.e. Saanich Inlet, Hamilton \& Hedges 1988; and Peru shelf areas, Henrichs \& Farrington 1984).

Reverse conveyor belt transport is believed to be a possible cause of subsurface peaks of tracers within sediment profiles (Soetaert et al. 1996), but until now there has been little evidence of organisms that behave in this way. Myers (1977) recorded that cirratulid polychaetes (such as Tharyx sp, at Stn SK, Fig. 8d) feed in this way. Boxcosm experiments showed that Echinocardium cordatum, which is capable of switching from subsurface-deposit feeding to surface-deposit feeding when large amounts of fresh algal material are present on the sea floor, enhances the transport of (highly degradable) organic matter to deeper sediment layers by fecal pellet deposition (Osinga et al. 1997). This species was present at $B F$, but even though it has been categorised as a diffusive mixer (Table 2), the extremely low biomass and minimal TOC content of the sediments do not allow us to identify significant variations in the vertical profiles (Fig. 3).

Generally, we hypothesise that diffusive mixing will be the most important bioturbation mechanism that transports nutritious surface particles up to depth within the range of subsurface-deposit feeders. In this manner deep-living subsurface-deposit feeders renew their food source by down-mixing. We suggest that the mineralization rate, a measure for the available energy for macrofauna (i.e. Tenore \& Rice 1980), at depth $L$ within the sediment is dependent on the quality of the arriving organic matter and the bioturbation rate. The results of the model (Fig. 9) can be interpreted as follows: for low quality material arriving at the sediment surface, the organic matter content of the sedlment will be high and the decrease in organic matter concentration with depth will be limited. The model predicts that bioturbation does not change the concentration at depth very much, because it tends to flatten an already flat curve. This scenario may be comparable to the conditions at SK, where low quality organic matter arrives at the sediment (Table 1). This is demonstrated by the high concentration and homogeneous TOC profiles at SK (Figs. 2 \& 3). Regarding the macrofaunal community structure, diffusive mixing is probably dominant (Fig. 8) at SK and animals are also able to live deep in the sediment (Fig 2). Since the quality of the organic matter is homogeneous with depth as well (Dauwe et al. unpubl.), a deep mode of living is not limited by the availability of food and may also be an important mechanism for escaping epibenthic predation.

For very high quality organic material, bioturbation does not increase the concentration at depth either, because the material tends to disappear before it reaches great depth, even when mixed vigorously. The fact that the station probably receiving the highest quality organic matter input (GB; as indicated by, e.g., the high chlorophyll a/TOC rate in the suspended matter, the high chlorophyll a concentration and the high bacterial biomass in the surface layer, Table 2) is influenced little by biodiffusive mixing supports the prediction of the model. Bioturbation rates would have to reach extremely high values to increase the mineralization rate at greater depth.

When the arriving material is of intermediate quality, however, the concentration profile is influenced most by biodiffusion, which tends to flatten it. This reflects the conditions in FF sediments. The sediments support a fauna dominated by extremely effective diffusive bioturbators (Callianassa subterranea) and show a relatively homogeneous depth distribution of TOC and macrofauna (Fig. 2). A peaked ingestion rate in subsurface-deposit feeders, which is equivalent to bioturbation rate, at some intermediate food value was also predicted by Taghon (1989, and references therein), based on models dealing with the energetic costs and benefits of subsurface-deposit feeding and on experimental data. The qualitative predictions of our model are also confirmed by the random walk model introduced by Wheatcroft et al. (1990), which links mechanistic properties of the benthic community to their bioturbation potential. This model estimates a (dimensionless) relative $D_{b}$ based on the individual size and total number of bioturbating organisms. The

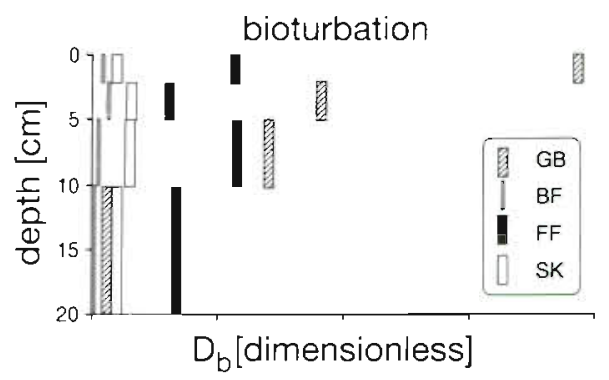

Fig. 10. Depth distribution of the dimensionless relative bioturbation coefficient $\left(D_{b}\right)$ estimated according to the relation $D_{b} \propto \delta^{2} / \Omega$, where $\delta=$ step length $=$ distance the particle is transported, $\Omega$ = rest period = time between the transportation events (Wheatcroft et al. 1990), based on the individual size and total number of bioturbating organisms. Station abbreviations as in Fig. 1 
authors showed that $D_{b}$ is directly proportional to the square of the distance particles are moved (step length) and inversely to the elapsed time between movements (rest period); $D_{b} \propto \delta^{2} / \Omega$, where $\delta=$ step length, $\Omega$ = rest period; and that both parameters can be related to (different) powers of body length. We applied this relation to estimate the bioturbation potential per depth stratum using the mean animal size of all organisms in the different depth strata, not accounting for the different bioturbation categories and feeding types (Fig. 10). The mechanistic model of Wheatcroft et al. (1990) (Fig. 10) supports our qualitative results since at FF, where large deposit feeders occur and material of intermediate quality arrives, the $D_{b}$ would be high at all depth strata. In contrast, at SK, where many but small animals live, $D_{b}$ would be lower, but also quite homogeneous with depth. At GB bioturbation would be concentrated to the upper strata and decrease drastically with depth in the sediment. The $D_{b}$ measurements based on modeling of the downcore distribution of chlorophyll a (Boon \& Duineveld 1998) confirm the extremely high bioturbation potential at FF.

In summary, our model predicts in qualitative terms that one should expect the most intense diffusive bioturbation activity in sediments whose arriving material is of intermediate quality. This result agrees well with the finding that subsurface-deposit feeders, protruding deep into the sediment and causing most of the diffusive mixing, dominate sediments containing intermediate to low quality organic matter, whereas nearsurface feeders, causing mainly biodeposition, are dominant in sediments containing a high amount of high quality organic matter.

The qualitative predictions of our model can be applied and tested by broad scale field studies, covering areas with fresh and with very refractory input, that quantify the quality and quantity of the organic matter input, measure bioturbation (e.g. by exponential fitting profiles of tracer profiles) and give a detailed vertical description of the macrofauna communities.

Acknowledgements. Adri Sandee and Piet de Koeyer are gratefully acknowledged for their assistance with sediment and macrofauna sampling. The crew of RV 'Pelagia' (NIOZ) are thanked for their support and for our pleasant stay during the cruise. E. Brummelhuis, W. Dimmers and W. Sistermans are thanked for their help with the macrofauna determinations. J. Craeymeersch, J. v. d. Koppel, J. Middelburg and J. Wijsman are thanked for their discussions and critical comments on the manuscript. Four anonymous reviewers are thanked for their constructive comments on the manuscript. The research was financially supported by the Netherlands Organisation for the Advancement of Science (NWO), project VvA, under grant 770-18-235. This is publication no. 2240 of the NIOO-CEMO.

\section{LITERATURE CITED}

Aller JY, Stupakoff I (1996) The distribution and seasonal characteristics of benthic communities on the Amazon shelf as indicators of physical processes. Cont Shelf Res 16:717-751

Barnes RD (1982) Invertebrate zoology. Holt Saunders, Tokyo

Berner RA (1980) Early diagenesis. A theoretical approach. Princeton University Press, Oxford

Blair NE, Levin LA, DeMaster DJ, Plaia G (1996) The shortterm fate of fresh algal carbon in continental slope sediments. Limnol Oceanogr 41:1208-1219

Boon AR, Duineveld GCA. (1996) Phytopigments and fatty acids as molecular markers for the quality of near-bottom particulate organic matter in the North Sea. J Sea Res 35:279-291

Boon AR, Duineveld GCA (1998) Chlorophyll a as a marker for bioturbation and carbon flux in southern and central North Sea sediments. Mar Ecol Prog Ser 162:33-43

Boudreau BP (1986a) Mathematics of tracer mixing in sediments. I. Spatially dependent, diffusive mixing. Am J Sci 286:161-198

Boudreau BP (1986b) Mathematics of tracer mixing in sediments. IT. Nonlocal mixing and biological conveyor-belt phenomena. Arn J Sci 286:199-238

Branch GM, Pringle A (1987) The impact of the prawn Callianassa kraussi Stebbing on sediment turnover and on bacteria, meiofauna, and benthic microflora. J Exp Mar Biol Ecol 107:217-235

Brown SL (1986) Feces of intertidal benthic invertebrates: influence of particle selection in feeding on trace element concentration. Mar Ecol Prog Ser 28:219-231

Creutzberg F. Wapenaar P, Duineveld $G$, Lopez N (1984) Distribution and density of the benthic fauna in the southern North Sea in relation to bottom characteristics and hydrographic conditions. Rapp P-V Réun Cons Int Explor Mer 183:101-110

Dando PR, Southward AJ (1986) Chemoautotrophy in bivalve molluscs of the genus Thyasira. J Mar Biol Assoc UK 66: 915-929

Dauer DM, Conner WG (1980) Effects of moderate sewage input on benthic polychaete populations. Estuar Coast Shelf Sci 10:335-346

Dauwe B, Middelburg JJ (1998) Amino acids and hexosamines as indicators of organic matter degradation state in North Sea sediments. Limnol Oceanogr 43:782-798

Dauwe B, Middelburg JJ, van Rijswijk P, Sinke J, Herman PMJ, Heip CHR (in press) Variations of enzymatically hydrolyzable amino acids in North Sea sediments and their possible implication for the nutritional value. J Mar Res

de Geu A, Baars MA, van der Veer HW (1991) De ecologie van het Friese Front. NIOZ rapport (Netherlands Institute of Sea Researchi, Texel

de Haas H, van Weering TCE (1997) Recent sediment accumulation, organic carbon burial and transport in the northeastern North Sea. Mar Geol 136:173-187

Dobbs FC, Guckert JB (1988) Callianassa trilobata (Crustacea: Thalassinidea) influences abundance of meiofauna and biomass, composition, and physiologic state of microbial communities within its burrow. Mar Ecol Prog Ser $45: 69-79$

Duineveld GCA, Künitzer A, Heyman RP (1987) Amphiura filiformis (Ophiuroidea:Echinodermata) in the North Sea. Distribution, present and former abundance and size composition. Neth J Sea Res 2:317-329

Eisma D, Kalf J (1987) Dispersal, concentration and deposition 
of suspended matter in the North Sea. $J$ Geol Soc (Lond) 144:161. -1.78

Eleftheriou A, Basford DJ (1989) The macrobenthic infauna of the offshore northern North Sea. J Mar Biol Assoc UK 69: $123-143$

Fauchald K, Jumars PA (1979) The diet of worms: a study of polychaete feeding guilds. Oceanogr Mar Biol Annu Rev 17:193-283

Flach E, Heip C (1996) Vertical distribution of macrozoobenthos within the sediment of the continental slope of the Goban Spur area (NE Atlantic). Mar Ecol Prog Ser 141 $55-66$

Forster S, Graf G (1995) Impact of irrigation on oxygen flux into the sediment: intermittent pumping by Callianassa subterranea and 'piston-pumping' by Lanice conchilega. Mar Biol 123:335-346

Gaston GR, DeAnna LL, Nasci JC (1988) Estuarine macrobenthos in Calcasieu Lake, Louisiana: community and trophic structure. Estuaries 11:192-200

Gaston GR, Nasci JC (1988) Trophic structure of macrobenthic communities in Calcasieu estuary, Louisiana. Estuaries 11:201-211

Gooday AJ, Turley CM (1990) Responses by benthic organisms to inputs of organic material to the ocean floor: a review. Phil Trans $R$ Soc Lond 331:119-138

Graf G (1989) Benthic-pelagic coupling in a deep-sea benthic community. Nature 341:437-439

Grebmeier JM, McRoy CP, Feder HM (1988) Pelagic-benthic. coupling on the shelf of the northern Bering and Chukchi Seas. I. Food supply source and benthic biomass. Mar Ecol Prog Ser 48:57-67

Grehan AJ, Scaps P, Desrosiers G, Juniper K, Stora G (1994) Vertical macrofaunal distribution in the soft sediments of the gulf of St. Lawrence and the Scotian continental margin: a preliminary assessment of intersite differences in bioturbation potential. Vie Milieu 44:101-107

Hamilton SE, Hedges JI (1988) The comparative geochemistries of lignin and carbohydrates in an anoxic fjord Geochim Cosmochim Acta 52:129-142

Heip C, Craeymeersch, JA (1995) Benthic community structures in the North Sea. Helgol Meeresunters 49:313-328

Henrichs SM, Farrington JW (1984) Peru upwelling region sediments near $15^{\circ} \mathrm{S}$. 1. Remineralization and accumulation of organic matter. Limnol Oceanogr 29:1-19

Hyland J, Baptiste E, Campbell J, Kennedey J, Kropp R, Williams S (1991) Macroinfaunal communities of the Santa Maria Basin on the California outer continental shelf and slope. Mar Ecol Prog Ser 78:147-161

Hylleberg J, Gallucci VF (1975) Selectivity in feeding by the deposit-feeding bivalve Macoma nasuta. Mar Biol 32: $167-178$

Jahnke RA, Emerson SR, Cochran. JK, Hirschberg DJ (1986) Fine scale distributions of porosity and particulate excess ${ }^{210} \mathrm{~Pb}$, organic carbon and $\mathrm{CaCO}_{3}$ in surface sediments of the deep equatorial Pacific. Earth Planet Sci Lett 77:59-69

Jangoux M, Lawrence JM (1982) Echinoderm nutrition. AA Balkema. Amsterdam

Jenness MI. Duineveld GCA (1985) Effects of tidal currents on chlorophyl a content of sandy sediments in the southern North Sea. Mar Ecol Prog Ser 21:283-287

Josefson AB (1985) Distribution and functional groups of marine benthic infauna in the Skagerrak (Eastern North Sea)-can larval availability affect diversity? Sarsia 70 $229-249$

Josefson AB (1986) Temporal heterogeneity in deep-water soft-sediment benthos: an attempt to reveal temporal structure. Estuar Coast Shelf Sci 23:147-169
Jumars PA, Nowell ARM, Self RFL (1981) A simple model of flow-sediment-organism interaction. Mar Geol 42:155-172

Koike I, Mukai H (1983) Oxygen and inorganic nitrogen contents and fluxes in the burrows of the shrimps Callianassa japonica and Upogebia major. Mar Ecol Prog Ser 12: $185-190$

Kube J, Powilleit M, Warzocha J (1996) The importance of hydrodynamic processes and food availability for the structure of macrofauna assemblages in the Pomerian Bay (Southern Baltic Sea). Arch Hydrobiol 138:213-228

Levin LA, Huggett CL, Wishner KF (1991) Control of deep-sea benthic community structure by oxygen and organic matter gradients in the eastern Pacific Ocean. J Mar Res 49:763-800

Levin L, Blair N, DeMaster D, Plaia G, Fornes W, Martin C, Thomas C (1997) Rapid subduction of organic matter by maldanid polychaetes of the North Carolina slope. J Mar Res 55:595-611

Lin J, Hines AH (1994) Effects of suspended food availability on the feeding mode and burial depth of the Baltic clam, Macoma batltica. Oikos 69:28-36

Lopez GR, Levinton IS (1987) Ecology of deposit-feeding animals in marine sediments. Q Rev Biol 62:235-260

Marsh AG, Tenore KR (1990) The role of nutrition in regulating the population dynamics of opportunistic, surface deposit feeders in a mesohaline community. Limnol Oceanogr 35:71.0-724

Mayer LM, Schick LL, Sawyer T, Plante CJ, Jumars PA, Self RFL (1995) Bioavailable amino acids in sediments: a biomimetic, kinetics-based approach. Limnol Oceanogr 40: $511-520$

Moodley L (1990) Southern North Sea seafloor and subsurface distribution of Living benthic foraminifera. Neth $\mathrm{J}$ Sea Res 27:57-71

Myers AC (1977) Sediment processing in a marine subtidaI sandy bottom community: I. Physical aspects. J Mar Res 35:609-632

Nickel LA, Atkinson RJA (1995) Functional morphology of burrows and trophic modes of three thalassinidean shrimp species, and a new approach to the classification of thalassinidean burrow morphology. Mar Ecol Prog Ser 128: $181-1.97$

Nieuwenhuize J, Maas YEM, Middelburg JJ (1994) Rapid analysis of organic carbon and nitrogen in particulate materials. Mar Chem 45:217-224

North Sea Task Force (1993) North Sea quality status report 1993. Oslo and Paris commissions, London. Olsen \& Olsen. Fredensborg

Ockelmann KW, Muus K (1978) The biology, ecology and behaviour of the bivalve Mysella bidentata. Ophelia 17: $1-93$

Osinga R, Kop AJ, Malschaert JFP, van Duyl FC (1997) Effects of the sea urchin Echinocardium cordatum on bacterial production and carbon flow in experimental benthic systems under increasing organic loading $\mathrm{J}$ Sea Res 37 $109-121$

Pearson TH. Rosenberg R (1978) Macrobenthic succession in relation to organic enrichment and pollution of the marine environment. Oceanogr Mar Biol Annu Rev 16:229-311

Pfannkuche $O$ (1993) Benthic response to the sedimentation of particulate organic matter at the BIOTRANS slation, $47^{\circ} \mathrm{N}, 20^{\circ} \mathrm{W}$. Deep-Sea Res 40:135-149

Phillips NW (1984) Role of different microbes and substrates as potential food suppliers of specific essential nutrients to marine detritivores. Bull Mar Sci 35:283-298

Posey $M H(1986)$ Changes in a benthic community associated with dense beds of a burrowing depositfeeder, Callianassa 
californiensis. Mar Ecol Prog Ser 31:15-22

Probert PK (1984) Disturbance, sediment stability, and trophic structure of soft-bottom communities. J Mar Res 42 : $893-921$

Rachor E (1990) Changes in sublittoral zoobenthos in the German Bight with regard to eutrophication. Neth I Sea Res 25:209-214

Rhoads DC (1974) Organism-sediment relations on the muddy sea floor. Oceanogr Mar Biol Annu Rev 12:263-300

Rhoads DC, Boyer LF (1982) The effects of marine benthos on physical properties of sediments: a successional perspective. In: McCall PL, Tevesz MJS (eds) Animal-sediment relations. Plenum Press, New York, p 3-52

Rhoads DC, Young DK (1970) The influence of deposit feeding organisms on sediment stability and community structure. J Mar Res 28:150-178

Romero-Wetzel MB, Gerlach SA (1991) Abundance, biomass, size-distribution and bioturbation potential of deep-sea macrozoobenthos on the Vorig Plateau (1200-1500 m, Norwegian Sea). Meeresforschung 33:247-265

Rosenberg R (1995) Benthic marine fauna structured by hydrodynamic processes and food availability. Neth J Sea Res 34:303-317

Rosenberg R, Dahl E, Edler L, Fyrberg L, Granéli E, Granéli W, Hagström $\AA$, Lindahl $O$, Matos MO, Petersson $K$, Sahlsten E, Tiselius P, Turek V, Wikner J (1990) Pelagic nutrient and energy transfer during spring in the open and coastal Skagerrak. Mar Ecol Prog Ser 61:215-231

Rosenberg R, Hellman B, Lundberg A (1996) Benthic macrofaunal community structure in the Norwegian trench. deep Skagerrak. J Sea Res 35:181-188

Rowden AA, Jones MB (1993) Critical evaluation of sediment turnover estimates for Callianassidae (Decapoda: Thalassinidae). J Exp Mar Biol Ecol 173:265-272

Schaffner LC, Diaz RJ, Olsen CR, Larsen IL (1987) Faunal characteristics and sediment accumulation processes in the James River estuary, Virginia. Estuar Coast Shelf Sci 25:211-226

Self RFL, Jumars PA (1978) New resource axes for deposit feeders? J Mar Res 36:627-641

Smith JN, Boudreau BP, Noshkin V (1986) Plutonium and ${ }^{210} \mathrm{~Pb}$ distributions, in northeast Atlantic sediments: subsurface anomalies caused by non-local mixing. Earth Planet Sci Lett 81:15-28

Snelgrove PVR, Butman CA (1994) Animal-sediment relationships revisited: cause versus effect. Oceanogr Mar Biol Annu Rev 32:111-177

Soetaert K, Herman PMJ, Middelburg JJ, Heip C, deStigter HS, van Weering TCE, Epping E, Helder W (1996) Modeling ${ }^{210} \mathrm{~Pb}$-derived mixing activity in ocean margin sediments: diffusive versus nonlocal mixing. J Mar Res 54: $1207-1227$

Stevens RL, Bengtsson H, Lepland A (1996) Textural provinces and transport interpretations with fine-grained sediments in the Skagerrak. J Sea Res 35:99-110

Taghon GL, Nowell ARM, Jumars PA (1980) Induction of suspension feeding in spionid polychaetes by high particulate fluxes. Science 210:562-564

Editorial responsibility: Otto Kinne (Editor), Oldendorf/Luhe, Germany
Taghon GL (1981) Beyond selection: optimal ingestion rate as a function of food value. Am Nat 118:202-214

Taghon GL (1982) Optimal foraging by deposit feeding invertebrates: roles of particle size and organic coating. Oecologia 52:295-304

Taghon GL (1989) Modelling deposit feeding. In: Lopez G, Taghon GL, Levinton J (eds) Ecology of marine deposit feeders. Springer Verlag, Berlin, p 223-246

Taghon GL, Greene RR (1992) Utilization of deposited and suspended particulate matter by benthic interface feeders. Limnol Oceanogr 37:1370-1391

Taylor AC, Davenport J, Allen JA (1995) Anoxic survival, oxygen consumption and haemocyanin characteristics in the protobranch bivalve Nucula sulcata Bronn. Comp Biochen Physiol 112:333-338

Tenore KR (1983) Organic nitrogen and caloric content of detritus III. Effect on growth of a deposit feeding polychaete, Capitella capitata. Estuar Coast Shelf Sci 17 : $733-742$

Tenore KR, Rice DL (1980): A review of trophic factors affecting secondary production of deposit-feeders. In: Tenore KR, Coull BC (eds) Marine benthic dynamics. Univ South Carolina, Columbia, SC, p 325-340

Valente RM, Rhoads DC, Germano JD, Cabelli VJ (1992) Mapping of benthic enrichment patterns in Narragansett Bay, Rhode Island. Estuaries 15:1-17

van Duyl FC., Kop AJ (1994) Bacterial production in North Sea sediments: clues to seasonal and spatial variations. Mar Biol 120:323-337

van Weering TCE, Berger GW, Okkels E (1993) Sediment transport, resuspension and accumulation rates in the northeastern Skagerrak. Mar Geol 111:269-285

van Weering TCE, Berger GW, Kalf J (1987) Recent sediment accumulation in the Skagerrak, northeastern North Sea. Neth J Sea Res 21:177-189

Weinberg JR (1984) Interactions between functional groups in soft-substrata: do species differences matter? J Exp Mar Biol Ecol 80:11-28

Weston DP (1990) Quantitative examination of macrobenthic community changes along an organic enrichment gradient. Mar Ecol Prog Ser 61:233-244

Wheatcr oft RA, Martin WR (1996) Spatial variation in shortterm $\left({ }^{234} \mathrm{Th}\right)$ sediment bioturbation intensity along an organic-carbon gradient. J Mar Res 54:763-792

Wheatcroft RA, Jumars PA, Smith CR, Nowell ARM (1990) A mechanistic view of particulate biodiffusion coefficient: step lengths, rest periods and transport directions. J Mar Res 48:177-207

Wheatcroft RA, Olmez I, Pink FX (1994) Particle bioturbation in Massachusetts Bay: preliminary results using a new deliberate tracer technique. J Mar Res 52:1129-1150

Wildish DJ, Peer D (1983) Tidal current speed and production of benthic marofauna in the lower Bay of Fundy. Can $J$ Fish Aquat Sci 40:309-321

Witbaard R, Duineveld GCA (1989) Some aspects of the biology and ecology of the burrowing shrimp Callianassa subterranea (Montagu) (Thalassinidea) from the southern North Sea. Sarsia 74:209-219

Submitted: February 23, 1998; Accepted: July 31, 1998

Proofs received from author(s): October 22, 1998 